\title{
Inhibition of Protein Kinase C Blocks Two Components of LTP Persistence, Leaving Initial Potentiation Intact
}

\author{
Patricia A. Colley, Fwu-Shan Sheu, and Aryeh Routtenberg \\ Cresap Neuroscience Laboratory, Northwestern University, Evanston, Illinois 60208
}

Protein kinase C (PKC) activity is increased following hippocampal long-term potentiation (LTP; Akers et al., 1986). A similar increase in PKC activity is measured following the induction of a long-lasting potentiation with abbreviated highfrequency stimulation (HFS) in combination with PKC-activating phorbol esters (Colley et al., 1989). Because phorbol esters have no effect on the initial potentiation produced with HFS, and because PKC activity appears to be related to the persistence of LTP and not to the initial change, we concluded that PKC regulates a post-initiation component of LTP. To define the time domain in which PKC activation is necessary for LTP, we studied the effect of the PKC inhibitors polymyxin B (PMXB) and 1-(5-isoquinolinesulfonyl)-2-methylpiperazine (H-7) micropressure ejected at different time points before and after the induction of LTP. LTP was produced in intact rats with HFS of the perforant path, and inhibitor ejections were made in the molecular layer of the dentate gyrus. PMXB, which at lower doses is a selective inhibitor of PKC, had no effect on initial potentiation, yet caused decay of the potentiated response to baseline within $2 \mathrm{hr}$. Decay occurred when PMXB was ejected 15 min before and 15 and 30 min after HFS. PMXB, at either low or high doses, was ineffective in blocking LTP persistence at time points greater than $\mathbf{3 0}$ min after HFS. Low doses of H-7 produced similar effects to those of PMXB. However, in contrast to a high dose of PMXB, a high dose of $\mathrm{H}-7$ inhibited the persistence of LTP when delivered 240 min after HFS. A decrease in the in vitro phosphorylation of the PKC substrate protein $F 1$ in animals that showed a decay of LTP following PMXB or $\mathrm{H}-7$ ejection suggests that PKC was inhibited in vivo. We propose a model of LTP that consists of 3 separable phases: (1) initial potentiation (0-5 $\mathrm{min})$, which does not require PKC activation; (2) a PKC-regulated persistence phase (5-60 min) related to synaptic modification; and (3) a second PKC-regulated persistence phase (>60 min), which is dependent on protein synthetic processes.

The $\mathrm{Ca}^{2+} /$ phospholipid-stimulated protein kinase $\mathrm{C}(\mathrm{PKC})$, which plays a key role in transmembrane signaling (Nishizuka, 1986, 1988) has been implicated by this (Routtenberg, 1985) and other laboratories (Malenka et al., 1986) in the regulation

\footnotetext{
Received Feb. 2, 1990; revised Apr. 30, 1990; accepted June 7, 1990.

This work was supported by grants MH25281-12 and AFOSR 90-0240 to A.R. We thank Frank Cutting, Greg Hoffman, and David Linden for helpful discussions.

Correspondence should be addressed to Dr. Aryeh Routtenberg, Cresap Neuroscience Laboratory, Northwestern University, Evanston, IL 60208.

Copyright (C) 1990 Society for Neuroscience $0270-6474 / 90 / 103353-08 \$ 03.00 / 0$
}

of hippocampal long-term potentiation (LTP), ${ }^{1}$ a model of information storage (Bliss and Lomo, 1973). Following the induction of LTP, both an increase in membrane PKC activity (Akers et al., 1986) and in vitro phosphorylation of a PKC substrate, protein F1 (Lovinger et al., 1985; Routtenberg et al., 1985), are detected. These biochemical alterations are positively correlated with the persistence of LTP, but not with the initial magnitude of the potentiated response. Finally, direct activation of PKC with phorbol esters enhances the persistence of synaptic potentiation produced with abbreviated high-frequency stimulation (HFS) without having an effect on initial potentiation (Routtenberg et al., 1986; Colley et al., 1989).

We have proposed a model in which phorbol esters and HFS act synergistically to produce a long-lasting synaptic potentiation. Although a slowly developing enhancement is induced with higher doses of phorbol ester alone (Malenka et al., 1986; Colley et al., 1989), current evidence suggests that phorbol ester enhancement differs from potentiation produced with HFS (Routtenberg et al., 1986; Gustafsson et al., 1988; Muller et al., 1988; Colley et al., 1989).

To determine whether PKC activation is necessary for LTP persistence, PKC inhibitors have been used. The first of such studies indicated that PKC was essential for the regulation of LTP persistence (Lovinger et al., 1987). Potentiated responses in the intact preparation decayed to baseline values within 50 min after ejections of 3 different PKC inhibitors [polymyxin B (PMXB), mellitin, and 1-(5-isoquinolinesulfonyl)-2-methylpiperazine (H-7)]. Mellitin (50 pmol), which was effective when applied $15 \mathrm{~min}$ before and 10-60 min after HFS, failed to produce decay if delivered $240 \mathrm{~min}$ after the induction of LTP. The data indicate that PKC activation maintains LTP for $15 \mathrm{~min}$, but not $240 \mathrm{~min}$, after its induction.

Inhibition of LTP persistence by extracellularly applied $\mathrm{H}-7$ and other PKC inhibitors has also been observed in hippocampal slice preparations (sphingosine: Malinow et al., 1988; K-252b: Reymann et al., 1988b; PMXB: Reymann et al., 1988a). The degree to which these compounds can inhibit the persistence of

\footnotetext{
${ }^{1}$ Because there now exist differences in terminology, we wish to define key words used in this report: $L T P$ has been used in the past to signify either procedure or effect. Here we refer to the procedure as high-frequency stimulation, or HFS and the effect after the procedure as LTP. The term initial potentiation is used here as the initial magnitude of potentiation immediatcly aftcr the 4-min pattcrn of HFS. Posttetanic potentiation (PTP; McNaughton, 1982) is only a component of this initial potentiation. The persistence of LTP is a measure of the maintenance of initial potentiation beyond PTP and, in the present report, is first measured 15 min after HFS. Similarly, the expression of LTP is a measure of the enhancement of synaptic transmission; it is used in the context of experiments in which expression is blocked without affecting the underlying mechanism. The term induction refers to the mechanism leading to persistent synaptic enhancement, whether it is produced by electrical or chemical manipulation.
} 
LTP may depend on their mode of PKC inhibition; for example, sphingosine, which acts on the regulatory subunit (Hannun et al., 1986), is ineffective if delivered after HFS, whereas inhibition of the catalytic subunit by H-7 (Hidaka et al., 1984) is effective when given either before or after the induction of LTP (Malinow et al., 1988). In addition, Malinow et al. (1988) produced decay with H-7 (300 $\mu \mathrm{M})$ applied $3 \mathrm{hr}$ after LTP induction, an effect not observed with mellitin ( 50 pmol; Lovinger et al., 1987). There has also been a report of $\mathrm{H}-7$ having no effect on LTP, but the dose used may have been too low (Muller et al., 1988). Finally, there have been recent reports of intracellularly injected PKC and CaM-dependent kinase inhibitors blocking LTP in CA1 neurons of hippocampal slices (Malenka et al., 1989; Malinow et al., 1989).

Discrepancies concerning the dose- and time-dependent effects of PKC inhibitors on hippocampal LTP might be explained by the differences in the preparation used, drug dose, and/or method of application. To determine the time domain when PKC activation is necessary for LTP persistence, we examined the dose-response effects of the PKC inhibitors PMXB and $\mathrm{H}-7$ delivered at discrete time points relative to the delivery of LTPinducing HFS. We also measured PKC activity following inhibitor application using in vitro phosphorylation of the PKC substrate protein $\mathrm{Fl}$ as the reporter system.

\section{Materials and Methods}

Electrophysiology. Experiments were performed on urethane-anesthetized Sprague-Dawley rats. Population EPSPs evoked by perforant path stimulation were recorded in the dentate gyrus molecular layer with micropipettes filled with inhibitor solutions. Stereotaxic placement of both stimulating and recording electrodes was performed as previously described (Routtenberg et al., 1985).

Inhibitors and micropressure ejection. Stock solutions of the PKC inhibitors PMXB (Sigma) and H-7 (Seikagaku America Inc.) were prepared with $20 \mathrm{~mm}$ Tris $(\mathrm{pH}, 7.5)$ to achieve a concentration of $10 \mathrm{~mm}$. Aliquots of stock solutions, stored at either $40^{\circ} \mathrm{C}(\mathrm{H}-7)$ or $-20^{\circ} \mathrm{C}(\mathrm{PMXB})$, were thawed and diluted as needed. Micropressure ejection of inhibitor solutions was performed using the techniques and equipment employed by McCrimmon et al. (1986), which have been previously described in detail (Lovinger et al., 1986). Ejection volumes were controlled by directly monitoring the movement of the solution miniscus in the micropipette with a $150 \times$ microscope (Rolyn Optics) and a fine reticule. Doses are reported as pmol drug ejected. Drug solutions were ejected in 5-nl vol unless the doses desired required concentrations greater than that of stock solutions. In these cases, equivalent ejections were achieved using 10-mM solutions ejected in vol up to $25 \mathrm{nl}$. Ejections of 5-25 nl $20 \mathrm{~mm}$ Tris vehicle or $\mathrm{H}-8$ (Seikagaku America Inc.), an isoquinolinesulfonamide derivative that is a much more potent inhibitor of cAMPdependent kinases than of PKC (Hidaka et al., 1984), were used for control ejections.

Recording and data analysis. Once stable baseline EPSPs evoked with $0.1 \mathrm{~Hz}$ stimulation were collected, 8 trains of $400-\mathrm{Hz}$ stimulation (8 pulses of $0.4 \mathrm{msec}$ ) were delivered to produce LTP $(40-60 \%$ increase over baseline) of EPSP slopes. The persistence of the LTP was then monitored with $0.1 \mathrm{~Hz}$ stimulation for up to $6 \mathrm{hr}$ after HFS.

Statistical analyses were performed on EPSP slopes elicited with threshold minus $2 \mathrm{~V}$. Threshold was defined prior to HFS as the baseline input voltage at which a population spike was first detected. This avoidcd population spikc contamination after HFS. Waveforms used for analysis were averages of 11 individual responses. Evoked waveforms were collected by an IBM PC-XT microcomputer and stored on disk for off-line analysis.

In vitro phosphorylation. Animals were killed 30-300 min after ejection of inhibitor as described (Lovinger et al., 1986). The area of the dorsal hippocampus surrounding the recording electrode was dissected $(\sim 30 \mathrm{mg})$ and homogenized at $4^{\circ} \mathrm{C}$. Aliquots were taken for an in vitro phosphorylation reaction, and proteins were separated by gel electrophoresis. The degree of ${ }^{32} \mathrm{P}$ incorporation from $\gamma-{ }^{32} \mathrm{P}$-ATP by the PKC substrate protein F1 was used as a measure of PKC activity. This was analyzed either by autoradiography or scintillation counting of bands cut from 1-dimensional gels.

\section{Results}

Experiment 1: selective blockade of LTP persistence by PMXB is dose dependent

When delivered $15 \mathrm{~min}$ before HFS, PMXB at doses lower than $50 \mathrm{pmol}$ had no effect on initial potentiation. Howcver, $45 \mathrm{~min}$ after HFS, decay of the potentiated response was observed (Fig. 1). The degree of decay increased with increasing doses of inhibitor within a narrow dose range. Thirteen pmol PMXB produced a $47 \%$ decay of LTP as compared to $19 \%$ decay following Tris ejections $(t=180 \mathrm{~min}$, paired $t=4.93, d f=3, p<0.02)$, whereas 25 pmol PMXB produced $100 \%$ decay (paired $t=$ $29.09, d f=3, p<0.0001$ ). With ejections of 50 and 100 pmol PMXB, the initial potentiation was reduced: $45 \%$ with ejections of $50 \mathrm{pmol}$ and $87 \%$ inhibition with ejections of $100 \mathrm{pmol}$ PMXB [1-way analysis of variance (ANOVA): $F=55.21 ; d f=$ $4,15 ; p<0.001]$. This observation may be explained by the ability of PMXB at higher doses to inhibit CaM-dependent kinase (Mazzei et al., 1982). Inhibitors of CaM-dependent kinase have been shown to block initial potentiation (Reymann et al., 1988b).

The inhibition of initial potentiation by higher doses of PMXB cannot be explained by an effect of inhibitor on baseline responses. In the absence of HFS, synaptic responses elicited with low-frequency stimulation remained stable for $90 \mathrm{~min}$ after ejection of 25, 50, or 100 pmol PMXB (data not shown).

\section{Experiment 2: selective blockage of LTP persistence by $P M X B$ is time dependent}

The time window in which PMXB inhibits LTP persistence was assessed using a dose of PMXB (25 pmol) that did not inhibit initial potentiation. PMXB ejected $15 \mathrm{~min}$ before or 15 or 30 min after HFS produced a decay of the potentiated response to near baseline values within 2-3 hr (Fig. 2). PMXB delivered 60 or 120 min after HFS showed no effects on LTP persistence as compared to Tris controls seen in Figure 1 (2-way ANOVA: $p$ $>0.20$ ). It was also noted that ejections of PMXB delivered 15 min before HFS produced a more rapid decay of potentiated responses as compared to ejections delivered 15 and $30 \mathrm{~min}$ after HFS (2-way ANOVA/drug $\times$ time interaction: $F=26.7$; $d f=12,63 ; p<0.001)$.

\section{Experiment 3: interaction of dose- and time-dependent effects} of $\mathrm{H}-7$ produces selective inhibition of LTP persistence

Another PKC inhibitor, H-7, was applied with similar time and ejection parameters as PMXB. PMXB inhibits PKC by competing with diacylglycerol for a site on the regulatory subunit (Mazzei et al., 1982), whereas H-7 acts on the catalytic subunit (Hidaka et al., 1984).

There was no effect of 50 or $250 \mathrm{pmol} \mathrm{H}-7$ on baseline synaptic activation (data not shown) or initial potentiation (Fig. 3; 1-way ANOVA: $p>0.20$ ). However, both 50 and $250 \mathrm{pmol} \mathrm{H}-7$ delivered $15 \mathrm{~min}$ before HFS produced decay of potentiated responses to baseline values (Fig. 3; 2-way ANOVA/drug $\times$ time interaction: $F-4.7$ and 7.3 , respectively; $d f=30,144 ; p<$ $0.001)$. Fifty pmol H-7 was also effective in inhibiting the persistence of LTP when ejected 15 or 30 min after HFS (Fig. 3). Although H-7 was much less effective when ejected 30 min after HFS than when ejected at earlier time points, it still produced a significantly greater decay of LTP than ejections of Tris vehicle 


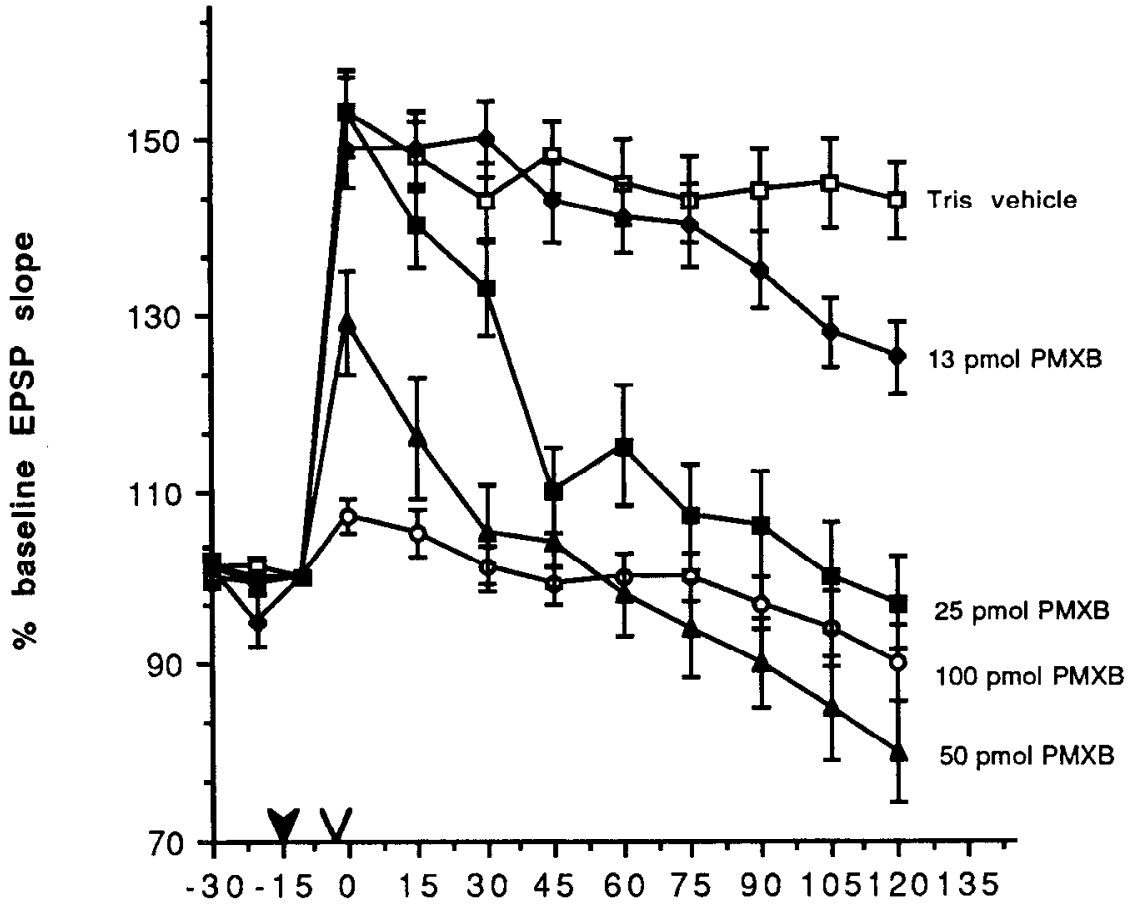

time (min)
Figure 1. Dose-dependent effects of PMXB on LTP. Ejections (thick arrowhead) of PMXB 15 min before HFS (thin arrowhead) produced dose-dependent inhibition of LTP. Lower doses (13 and $25 \mathrm{pmol}$ ) inhibited the persistence of LTP but not initial potentiation, causing decay of LTP to baseline by 120 min after HFS (2-way ANOVA/drug $\times$ time interaction of $25 \mathrm{pmol}$ PMXB: $F$ $=3.9 ; d f=12,78 ; p<0.001)$. Higher doses (50 and $100 \mathrm{pmol}$ ) attenuated initial potentiation, as well $(N=4$ per group). Error bars represent SEM values. or the A kinase inhibitor H-8 (Fig. 3; 2-way ANOVA/drug effect: $F=4.8 ; d f=2,108 ; p<0.025)$.

Ejcctions of 50 pmol H-7 given 60, 120, and 240 min after HFS had no effect on LTP persistence (Fig. $4 ; p>0.20$ ). However, $250 \mathrm{pmol} \mathrm{H-7} \mathrm{delivered} 240 \mathrm{~min}$ after HFS was capable of producing a decay of potentiated responses (Figs. 4, 5; 2-way
ANOVA: $F=9.4 ; d f=3,288 ; p<0.05$ ). A comparison of the rates of LTP decay following $\mathrm{H}-7$ at different time points showed a significantly slower rate of decay following ejections of 250 pmol H-7 240 min after HFS than after low- and high-dose $\mathrm{H}-7$ ejections at earlier time points (1-way ANOVA: $F=5.11$; $d f=$ 3,$12 ; p<0.05$; Fig. 6 ).

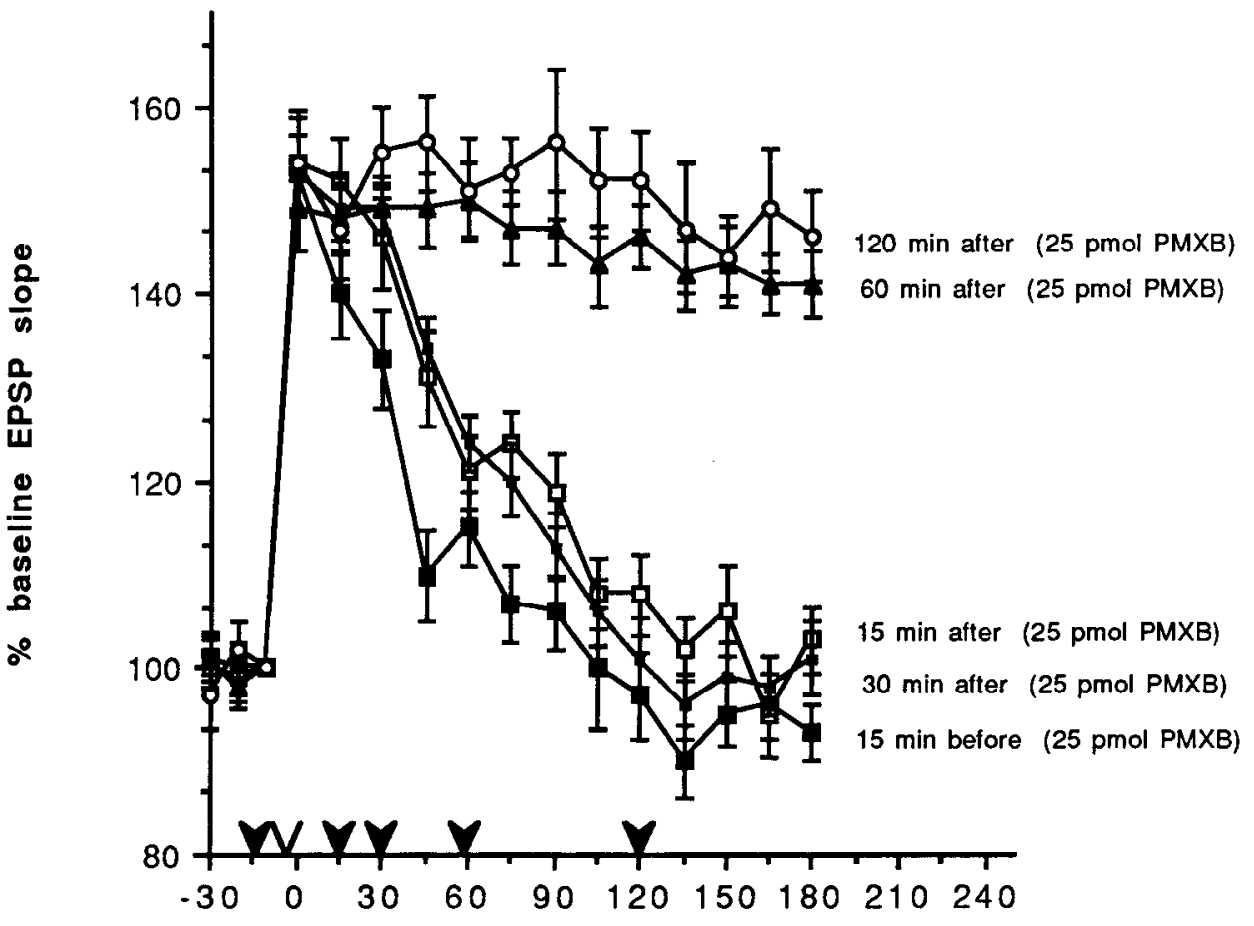

time (min)
Figure 2. Time course of PMXB inhibition of LTP persistence. Ejections of 25 pmol PMXB (thick arrowheads) were effective in producing decay of the LTP response when delivered up to 30 min after LTP HFS (thin arrowhead). Ejections delivered 60 and $120 \mathrm{~min}$ after HFS, however, had no effect on LTP, as did the Tris controls in Figure $1(N$ $=4$ per group). Error bars represent SEM values. 
Figure 3. H-7, like PMXB, inhibits LTP persistence without affecting the initial potentiation. Ejections of $\mathrm{H}-7$ (thick arrowheads) 15 min before and up to $30 \mathrm{~min}$ after HFS (thin arrowheads) significantly inhibited LTP persistence as compared to H-8 (a cAMP kinase inhibitor) or Tris controls $(N=$ 4 per group). Neither 50 nor 250 pmol $\mathrm{H}-7$ ejected before HFS had an affect on initial potentiation. Error bars represent SEM values.

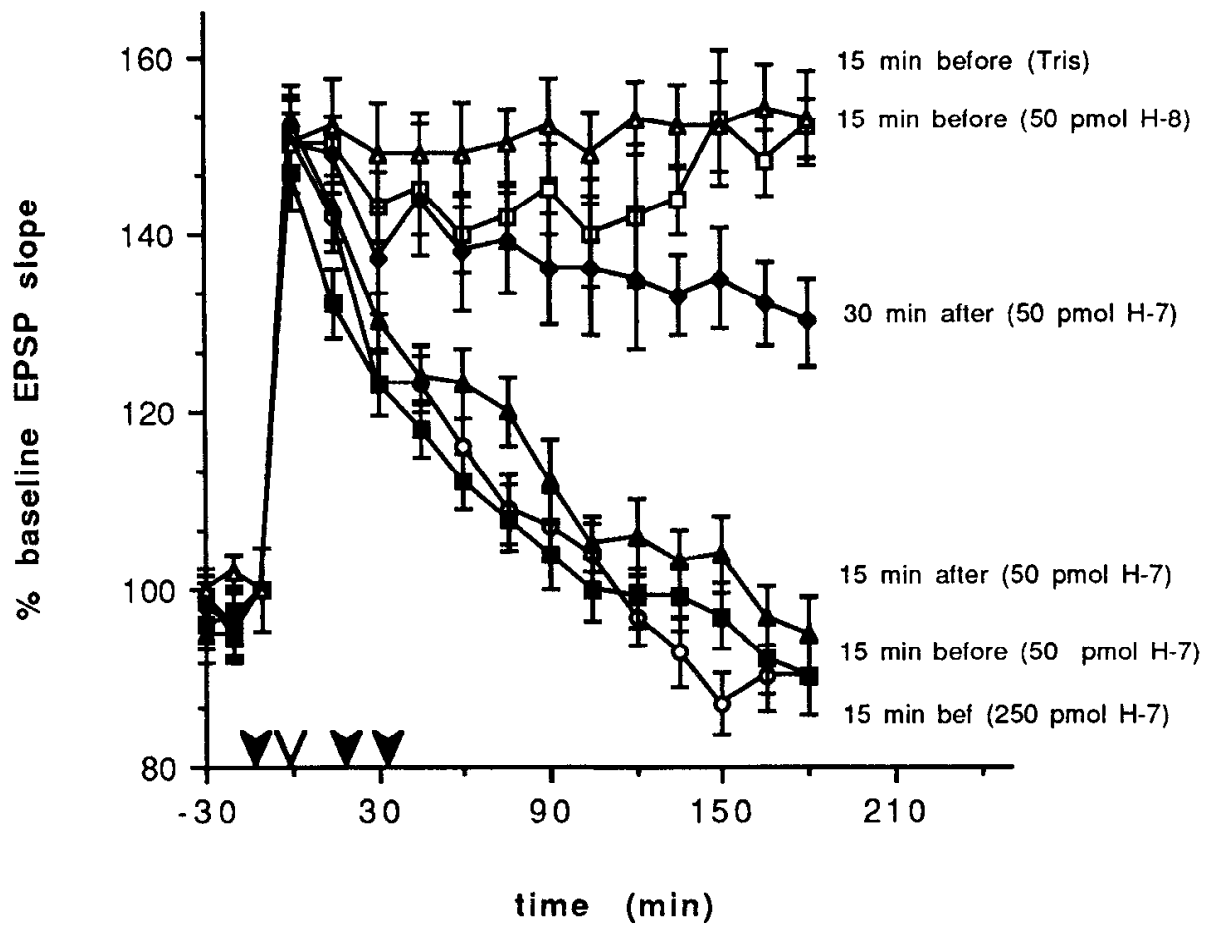

To insure that the lack of inhibitory effect of low-dose ejections delivered $240 \mathrm{~min}$ after the induction of LTP was not due to loss of inhibitor potency with time in the micropipette, inhibitor solutions were kept at room temperature for $240 \mathrm{~min}$ before testing their cffectiveness in inhibiting LTP. These drug solutions showed inhibition of LTP persistence similar to solutions used immediately after thawing (data not shown).
Experiment 4: In vitro phosphorylation of hippocampal protein F1 following inhibition of LTP persistence with $P K C$ inhibitors

To determine whether the inhibition of LTP by PMXB or H-7 was related to an inhibition of PKC activity, we measured PKC substrate phosphorylation $30 \mathrm{~min}$ after treatment with PKC
Figure 4. High dose of $\mathrm{H}-7$ blocks late component of LTP. Ejections of $50 \mathrm{pmol}$ (thick arrowheads) fuil to inhibit LTP persistence when delivered 120 and 240 min after induction (thin arrowhead). Two-hundred fifty pmol H-7, however delivered $240 \mathrm{~min}$ after HFS produced a significant decay of LTP over $120 \mathrm{~min}$ after ejection ( $N=4$ per group). Error bars represent SEM values.

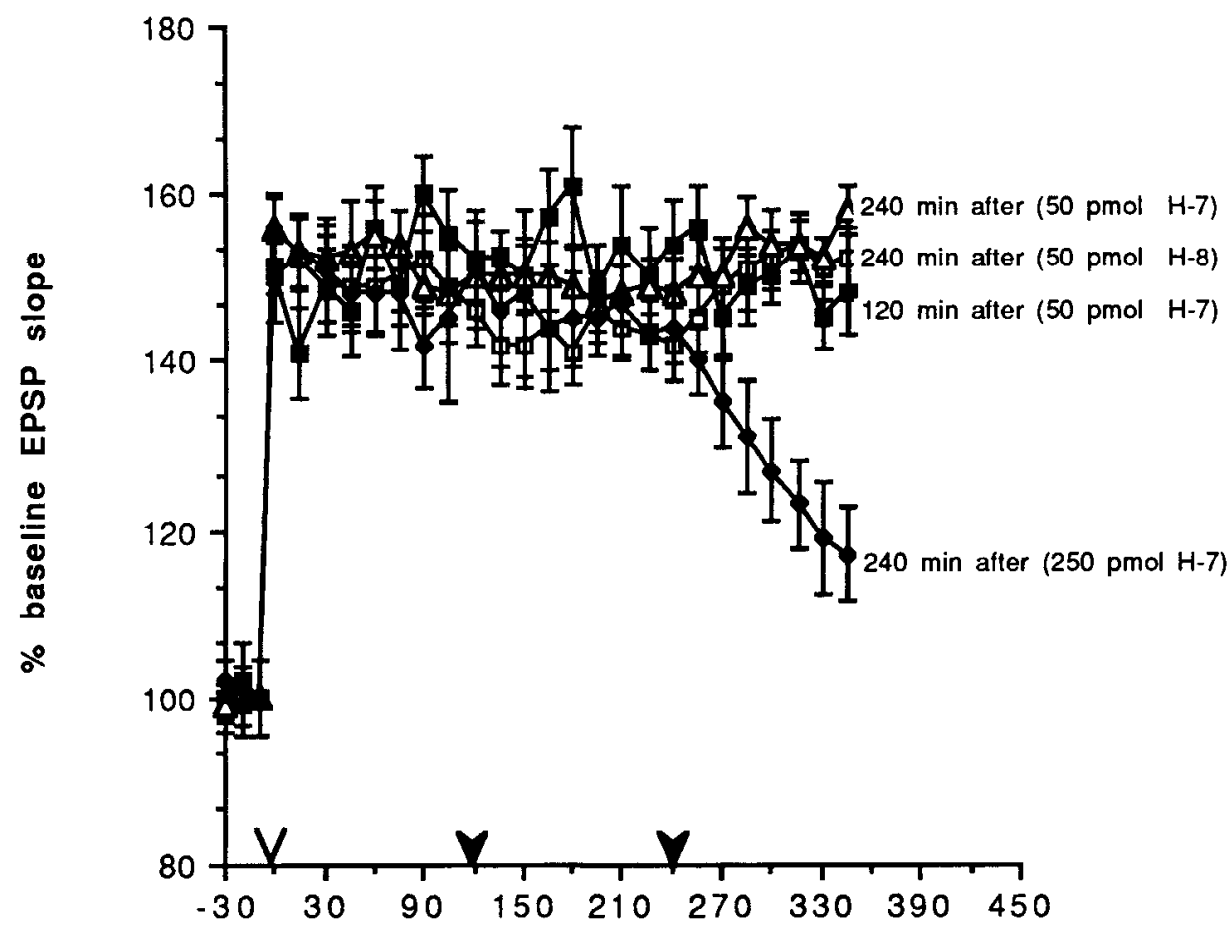

time $(\mathrm{min})$ 


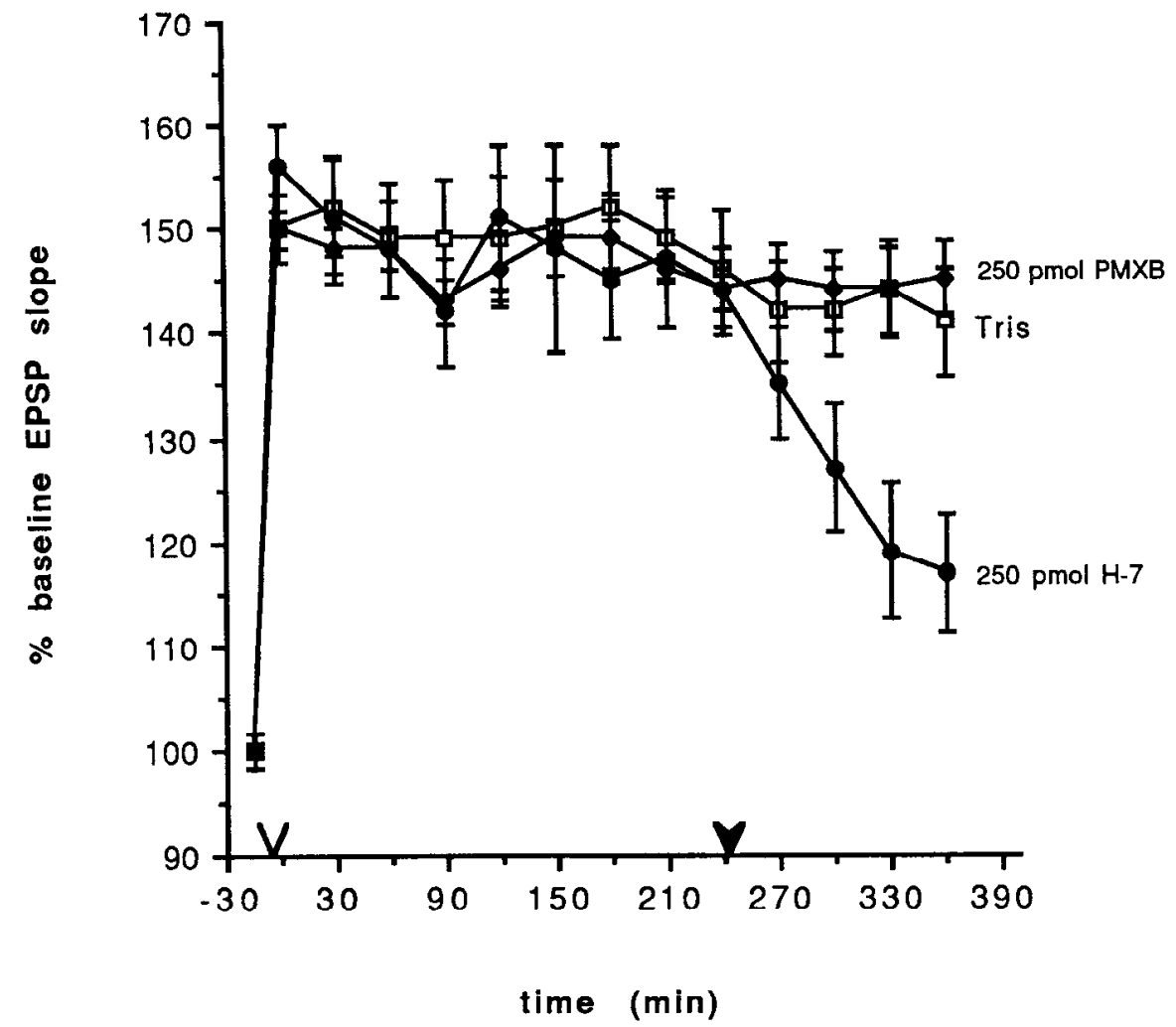

Figure 5. Unlike high dose $(250 \mathrm{pmol})$ of H-7 (Fig. 4), PMXB (250 pmol) delivered $240 \mathrm{~min}$ (thick arrowhead) after HFS (thin arrowhead) failed to produce decay of LTP ( $N=4$ per group). Error bars represent SEM values. inhibitors and HFS. To determine whether inhibitors ejected in vivo might be having their effect directly on the in vitro reaction rather than in vivo, PMXB was delivered in LTP animals immediately before death (in vitro phosphorylation controls).

Animals that received ejections of either H-7 or PMXB immediately before HFS showed a significant decrease in the in vitro phosphorylation of the PKC substrate protein F1 as com- pared to LTP controls (1-way ANOVA: $F=7.81 ; d f=1,10 ; p$ $<0.025)$. Both LTP animals and in vitro phosphorylation controls showed greater levels of protein F1 phosphorylation as compared to animals that received only low-frequency stimulation (1-way ANOVA: $F=8.71$ and $11.83, d f=1,6 ; p<0.05$ and 0.025 , respectively), suggesting that the $\mathrm{PKC}$ inhibitors $\mathrm{PMXB}$ and $\mathrm{H}-7$ are affecting an in vivo process rather than the

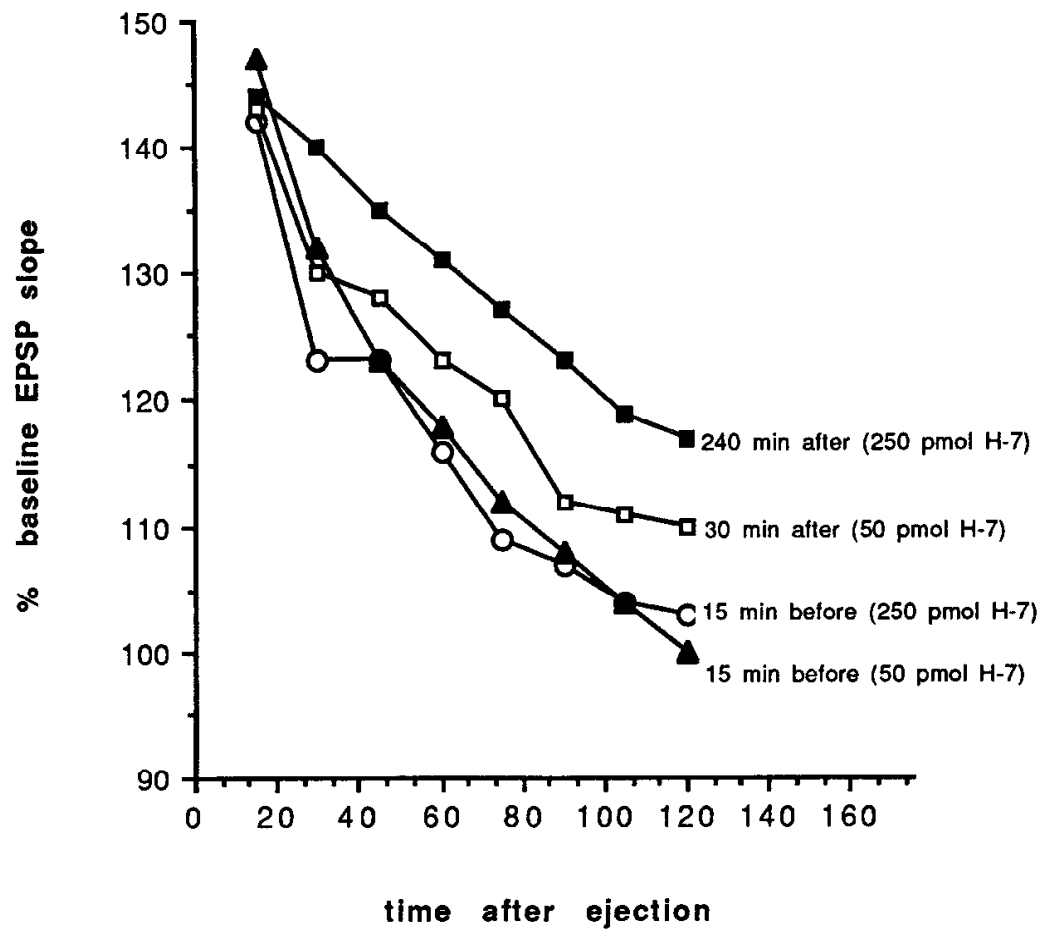

Figure 6. Comparison of decay rates following ejections of $\mathrm{H}-7$ at different time points. The rate of decay following 250 pmol $\mathrm{H}-7$ ejected $240 \mathrm{~min}$ after HFS is significantly slower than LTP decay following ejections $15 \mathrm{~min}$ before ( 50 and $250 \mathrm{pmol}$ ) or $30 \mathrm{~min}$ after HFS (1-way ANOVA comparing all groups: $F=5.11 ; d f=3,12 ; p<0.05)$. Decay rate was calculated as the mean change in percent of baseline EPSP slope over each 15 min interval. 
Table 1. Effect of PKC inhibitor ejections and LTP on in vitro phosphorylation of PKC substrate protein F1

\begin{tabular}{llll} 
& $\begin{array}{l}\text { Number } \\
\text { of hip- } \\
\text { pocampi } \\
\text { sampled }\end{array}$ & $\begin{array}{l}\text { Protein F1 } \\
{ }^{32} \text { incorpora- } \\
\text { tion cpm) }\end{array}$ & $\begin{array}{l}\text { Percent } \\
\text { baseline } \\
\text { EPSP slope } \\
\text { (after 30 } \\
\text { min) }\end{array}$ \\
\hline Group & & & \\
\hline Low-frequency control & 4 & $634.3 \pm 17.4$ & $101 \pm 5.42$ \\
$\quad(0.1 \mathrm{~Hz})$ & 4 & $753.0 \pm 36.4$ & $149 \pm 6.59$ \\
LTP alone & 5 & $509.3 \pm 97.4$ & $104 \pm 7.67$ \\
LTP plus PMXB & 4 & $480.0 \pm 89.9$ & $107 \pm 4.76$ \\
LTP plus H-7 & & & \\
$\begin{array}{l}\text { In vitro } \text { phosphorylation } \\
\quad \text { control }\end{array}$ & 4 & $713.7 \pm 15.2$ & $137 \pm 5.03$
\end{tabular}

The percentage of ${ }^{32} \mathrm{P}$ incorporated into protein $\mathrm{F} 1$ was significantly greater in LTP and in vitro phosphorylation controls (see ${ }^{c}$ below) than in animals that received PKC inhibitors 15 min prior to HFS or low-frequency controls (1-way ANOVA: $F=15.82$ and 18.31 , respectively; $d f=3,12 ; p<0.001$ ).

${ }^{b}$ The degree of potentiation at $30 \mathrm{~min}$ after LTP induction was significantly greater in animals that received HFS alone than in animals that received either PMXB or H-7 prior to HFS (1-way ANOVA: $F=10.82$ and 27.58 , respectively; $d f=$ 1,$7 ; p<0.01$ ) and low-frequency controls (1-way ANOVA: $F=31.99 ; d f=1,7$; $p<0.001)$.

c In vitro phosphorylation control: LTP animals received ejections of PMXB immediately before death and, because this had no electrophysiological effect, were physiologically identical to LTP controls.

in vitro phosphorylation assay directly. This in vivo process is likely to be the PKC activation induced by LTP (Akers et al., 1986) because the alternative, that the in vitro phosphorylation assay is measuring an increase in vacant sites after LTP, would predict an increase in protein $\mathrm{F} 1$ phosphorylation after ejection of PKC inhibitors.

We tested whether PKC activity, as measured by F1 substrate phosphorylation, is related to the persistence of LTP $240 \mathrm{~min}$ after its induction. Animals receiving only low-frequency stimulation $(0.1 \mathrm{~Hz})$ or $400 \mathrm{~Hz}$ stimulation to produce LTP and monitored for $5 \mathrm{hr}$ were used as controls. Experimental groups consisted of animals that received either 50 or $250 \mathrm{pmol} \mathrm{H}-7$ $180 \mathrm{~min}$ after HFS. Only the 250 -pmol group showed significant decay of LTP over an additional $2 \mathrm{hr}$ (Table 2).

LTP controls showed higher protein Fl phosphorylation $5 \mathrm{hr}$ after HFS as compared to low-frequency controls (1-way ANOVA: $F=9.97 ; d f=1,9 ; p<0.05$; Table 2 ). In addition, protein FI phosphorylation was lower in animals that received 250 pmol H-7 $3 \mathrm{hr}$ after HFS and showed decay of the LTP than in animals that received HFS alone (1-way ANOVA: $F=8.05$; $d f=1,10 ; p<0.05$; Table 2). Animals that received 50 pmol H-7 $3 \mathrm{hr}$ after HFS showed protein F1 phosphorylation levels intermediate to those seen in LTP controls and animals receiving $250 \mathrm{pmol} \mathrm{H}-73 \mathrm{hr}$ after HFS.

\section{Discussion}

We conclude from these data that PKC activation is important for the persistence of LTP, but not for initial potentiation. As summarized in Table 3, it has previously been demonstrated that extracellular PKC inhibitors have no effect on initial potentiation, yet produce decay to baseline of LTP both in the intact hippocampus (Lovinger et al., 1987) and in the hippocampal slice preparation (Malinow et al., 1988; Reymann et al., $1988 \mathrm{a}, \mathrm{b})$. In the present study, a low dose of PMXB or a range of $\mathrm{H}-7$ doses ejected prior to HFS also had no effect on initial
Table 2. In vitro phosphorylation of protein F1 5 hr after the induction of LTP: does H-7 delivered $3 \mathrm{hr}$ after HFS inhibit PKC substrate phosphorylation?

\begin{tabular}{llll} 
Group & $\begin{array}{l}\text { Number } \\
\text { of hip- } \\
\text { pocampi } \\
\text { sampled }\end{array}$ & $\begin{array}{l}\text { Protein F1 } \\
\text { (\% total } \text { P }^{32} \\
\text { incorpo- } \\
\text { ration) }\end{array}$ & $\begin{array}{l}\text { Percent } \\
\text { baseline EPSP } \\
\text { slope (after 5 } \\
\text { hr) }\end{array}$ \\
\hline $0.1 \mathrm{~Hz}$ control & 5 & $4 \pm 0.41$ & $98 \pm 3.21$ \\
LTP alone & 5 & $6 \pm 0.47$ & $140 \pm 4.43$ \\
LTP plus 50 pmol H-7 & 4 & $6 \pm 0.63$ & $145 \pm 3.80$ \\
LTP plus 250 pmol H-7 & 4 & $4 \pm 0.25$ & $127 \pm 5.54$
\end{tabular}

${ }^{a}$ Animals that received 250 pmol H-7 $3 \mathrm{hr}$ after LTP induction to produce decay of LTP showed similar levels of protein F1 phosphorylation to those seen in lowfrequency controls and significantly lower levels of protein $F 1$ phosphorylation as compared to LTP controls (1-way ANOVA: $F=8.05 ; d f=1,10 ; p<0.05$ ).

potentiation, but produced a decay to baseline of the potentiated response.

It has been reported that intracellular injections of $\mathrm{H}-7$ into CA1 pyramidal cells blocked LTP in hippocampal slices (Malinow et al., 1989). Although not discussed, their Figure 1 shows that intracellular injection of $\mathrm{H}-7$ reduced initial potentiation of the intracellular response. Such an effect of $\mathrm{H}-7$ was not observed in the present study.

Three possible explanations for the discrepancy may be suggested: (1) high doses of H-7 (200 mM) used by Malinow et al. (1989) may have nonselective effects, (2) the perforant pathgranule cell synapses express a different set of PKC subtypes than CA1 pyramidal synapses, or (3) procedural differences such as in vivo versus in vitro preparation or intracellular versus extracellular drug application. The first explanation should be considered in view of a related study that showed that lower doses (20 mM) of $\mathrm{H}-7$ intracellularly injected into CAl cells in vitro had no effect on initial potentiation, but resulted in the total decay of LTP $30 \mathrm{~min}$ after HFS (Malenka et al., 1989).

Another conclusion we draw from the present data is that the persistence of LTP consists of 2 separable components, both of which may require PKC activation. Malinow et al. (1988), perfusing a 300- $\mu \mathrm{M}$ solution of $\mathrm{H}-7$ in a hippocampal slice preparation, showed that LTP expression could be inhibited with applications as late as $3 \mathrm{hr}$ after induction. This late inhibition of LTP by H-7 is now proposed by Malinow et al. (1989) to be mediated by effects of $\mathrm{H}-7$ at the presynaptic terminal because intracellular postsynaptic injection of $\mathrm{H}-7$ into $\mathrm{CAl}$ pyramidal cells blocks the induction of LTP but has no effect on established LTP. In the present study, a high dose of $\mathrm{H}-7$ is effective in inhibiting LTP persistence when applied $240 \mathrm{~min}$ after HFS. Because the same dose does not affect responses elicited with low-frequency stimulation for $90 \mathrm{~min}$ after ejection, this dose is not nonspecifically altering synaptic transmission. Interestingly, the rate of LTP decay following $250 \mathrm{pmol} \mathrm{H-7} 240 \mathrm{~min}$ aftcr LTP induction is significantly slower than decay following earlier $\mathrm{H}-7$ ejections. These observations suggest that, at this later time point, $\mathrm{H}-7$ is having an effect on a process that appears to be either more resistant to PKC inhibitors or at a distance from the site of inhibitor ejection.

Based on these later effects of $\mathrm{H}-7$ on LTP persistence, we suggest that there are at least 3 mechanistically separable events. First, HFS triggers the voltage-dependent release of $\mathbf{M g}^{2+}$ blockade of postsynaptic NMDA receptor-associated $\mathrm{Ca}^{2+}$ channels 
Table 3. Summary of PKC inhibitor studies

\begin{tabular}{|c|c|c|c|c|}
\hline Study & Preparation & Inhibitor(s) & Extracellular application $^{a}$ & $\begin{array}{l}\text { Effect on LTP } \\
\text { persistence }{ }^{b}\end{array}$ \\
\hline Colley et al., this study & Dentate in vivo & PMXB, H-7 & 25-250-pmol ejections & inhibition up to $240 \mathrm{~min}$ \\
\hline Lovinger et al., 1987 & Dentate in vivo & PMXB, mellitin, H-7 & 50-pmol ejections & inhibition, but not at $240 \mathrm{~min}$ \\
\hline \multicolumn{5}{|l|}{ Malinow et al., 1988, } \\
\hline 1989 & CAl slice & $\mathrm{H}-7$ & $300-\mu \mathrm{M}, 3-8-\mathrm{hr}$ perfusion & inhibition up to $3 \mathrm{hr}$ \\
\hline Muller et al., 1988 & CAl slice & $\mathrm{H}-7$ & $100-\mu \mathrm{M}, 20-\mathrm{min}$ static bath & no inhibition \\
\hline Reymann et al., 1988a & CAl slice & PMXB & $20-\mu \mathrm{M}, 60-$ min perfusion & inhibition \\
\hline
\end{tabular}

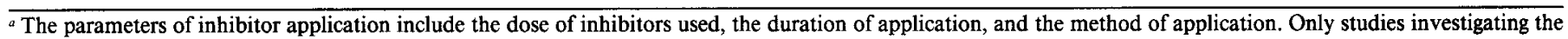
effect of extracellular inhibitor application are included in the table for reasons of comparison.

${ }^{b}$ References to time indicate the time after initiation of LTP at which inhibitors are still effective in producing decay of LTP.

allowing for a transient influx of $\mathrm{Ca}^{2+}$ (Collingridge, 1985). The resulting initial potentiation is mediated, at least in part, through activation of a CaM-dependent kinase (Popov et al., 1988; Reymann et al., 1988b). These events may regulate an increased sensitivity of quisqualate/kainate-type receptors after LTP (Collingridge and Lester, 1988; Davies et al., 1989).

Second, presynaptic PKC is activated, and subsequently, protein $F 1$ is phosphorylated, possibly via a retrograde mechanism (Linden and Routtenberg, 1989). This event may regulate the persistence of potentiation for 5-60 min after HFS (Lovinger et al., 1987; Matthies, 1989).

Third, protein synthesis is initiated ( $>60$ min after HFS) to provide a long-lasting synaptic enhancement (Krug et al., 1984; Stanton and Sarvey, 1984; Frey et al., 1988; Cole et al., 1989; Otani and Abraham, 1989). This protein-synthetic event mediating the long-term persistence of LTP may be regulated by PKC (Imagawa et al., 1987; Lee et al., 1987; Reymann et al., 1988a).

It is known that protein-synthetic events can be regulated by PKC- as well as cAMP-dependent processes. cAMP-dependent kinases have been shown to regulate the induction of RNA and protein synthesis of at least some proteins via nuclear protein phosphorylation (Imagawa et al., 1987; Yamamoto et al., 1988). A possible role of CAMP in the regulation of a later persistence phase of LTP is interesting in view of evidence that cAMP regulation of protein synthesis has been proposed in invertebrates to underly other forms of long-term synaptic change (Goelet et al., 1986). However, our results show that the cyclic nucleotide inhibitor $\mathrm{H}-8$ failed to have an effect on LTP persistence at a time point when a high dose of $\mathrm{H}-7$ was effective in producing decay of LTP. This observation argues against a role of CAMP in the regulation of long-term persistence of LTP.

If the late component of LTP persistence is not regulated by cAMP, PKC activation may be required for protein synthetic events associated with LTP. This suggestion is consistent with the observed decrease in PKC substrate phosphorylation in animals that received $250 \mathrm{pmol} \mathrm{H-7,} \mathrm{a} \mathrm{dose} \mathrm{effective} \mathrm{in} \mathrm{producing}$ decay of LTP 3 and $4 \mathrm{hr}$ after its induction (Table 2).

The present data therefore suggest that the 2 components of LTP persistence may both be regulated by PKC activation, but by different mechanisms. We propose that the early component of LTP persistence, which in the present report is first measured 15 min after HFS, is mediated by translocation of PKC activity to the synaptic membrane and subsequent synaptic protein phosphorylation. The later component of LTP persistence $(>60$ min) may be mediated by PKC regulation of protein synthesis.
By what mechanism is persistent PKC maintained? Malinow et al. (1988) suggested that, at later time points, PKC activation may be maintained in the absence of activators, that is, cleavage of the catalytic from the regulatory subunit, or by long-lasting translocation of the kinase to the surface membrane. If the cleaved catalytic subunit of PKC is responsible for persistent PKC activity after LTP, only PKC inhibitors such as $\mathrm{H}-7$ acting at the catalytic site should be effective. This prediction was confirmed in the present report.

PKC has been identified as a class of several closely related enzymes (Coussens et al., 1986; Knopf et al., 1986; Ono et al., 1987; Nishizuka, 1988) that can be differentiated on the basis of sensitivity to activators (Nishizuka, 1988; Sekiguchi et al., 1987), as well as regional (Brandt et al., 1987; Huang et al., 1987,1988 ) and subcellular localization in the brain (Leach et al., 1989; for review, see Huang, 1989). The possibility exists, then, that these 2 phases of LTP persistence could be regulated by different PKC subtypes.

\section{References}

Akers RF, Lovinger DM, Colley PA, Linden DJ, Routtenberg A (1986) Translocation of protein kinase $\mathrm{C}$ activity may mediate hippocampal long-term potentiation. Science 231:374-378.

Bliss TVP, Lomo T (1973) Long-lasting potentiation of synaptic transmission in the dentate area of the anesthetized rabbit following stimulation of the perforant path. J Physiol (Lond) 233:334-356.

Brandt SJ, Niedel JE, Bell RM, Young WS III (1987) Distinct patterns of expression of different protein kinase $C \mathrm{mRNAs}$ in rat tissue. Cell 49:57-63.

Cole AJ, Saffen DW, Baraban JM, Worley PF (1989) Rapid increase of an immediate early gene messenger RNA in hippocampal neurons by synaptic NMDA receptor activation. Nature 340:474-476.

Colley PA, Sheu F-S, Routtenberg A (1989) Dose-dependent phorbol ester facilitation or blockade of hippocampal long-term potentiation: relation to membrane/cytosol distribution of protein kinase $\mathrm{C}$ activity. Brain Res 495:205-216.

Collingridge GL (1985) Long-term potentiation in the hippocampus: mechanisms of initiation and modulation by neurotransmitters. Trends Pharmacol Sci 6:407-411.

Collingridge GL, Lester RAJ (1988) The sensitivity of CAl neurones to quisqualate following high-frequency stimulation in rat hippocampus in vitro. J Physiol (Lond) 398:22P.

Coussens L, Parker PJ, Rhee L, Yang-Feng TL, Chen E, Watcrficld MD, Francke U, Ullrich A (1986) Multiple distinct forms of bovine and human protein kinase $C$ suggest diversity in cellular signalling pathways. Science 233:859-866.

Davies SN, Lester RAJ, Reymann KG, Collingridge GL (1989) Temporally distinct pre- and post-synaptic mechanisms maintain longterm potentiation. Nature 388:500-503.

Frey U, Krug M, Reymann K, Matthies H (1988) Anisomycin, a 
inhibitor of protein synthesis, blocks late phases of LTP phenomena in the hippocampal CA1 region in vitro. Brain Res 452:57-65.

Goelet P, Castellucci VF, Schacter S, Kandel ER (1986) The long and the short of long-term memory-a molecular framework. Nature 322: 419-422.

Gustafsson B, Huang Y-Y, Wigstrom H (1988) Phorbol ester-induced synaptic potentiation differs from long-term potentiation in the guinea pig hippocampus in vitro. Neurosci Lett 85:77-81.

Hannun YA, Loomis CR, Merrill AH Jr, Bell RM (1986) Sphingosine inhibition of protein kinase $C$ activity and of phorbol dibutyrate binding in vitro and in human platelets. J Biol Chem 261:1260412606.

Hidaka H, Inagaki M, Kawamoto S, Sasaki Y (1984) Isoquinolinesulfonamides, novel and potent inhibitors of cyclic nucleotide-dependent protein kinase and protein kinase C. Biochemistry 23:50365041.

Huang FL, Yoshida Y, Nakabayashi H, Huang K-P (1987) Differential distribution of protein kinase $\mathrm{C}$ isozymes in the various regions of brain. J Biol Chem 262:15714-15720.

Huang FL, Yoshida Y, Nakabayashi H, Young WS, Huang K-P (1988) Immunocytochemical localization of protein kinase $\mathrm{C}$ isozymes in rat brain. J Neurosci 8:4734-4744.

Huang K-P (1989) The mechanism of protein kinase C activation. TINS 12:425-432.

Imagawa M, Chiu R, Karin M (1987) Transcriptional factor AP-2 mediates induction by two different signal transduction pathways: protein kinase $\mathrm{C}$ and cAMP. Cell 51:251-260.

Knopf JL, Lee M-H, Sultzman LA, Kriz RW, Loomis CR, Hewick RM, Bell RM (1986) Cloning and expression of multiple protein kinase C cDNAs. Cell 46:491-502.

Krug M, Lossner B, Ott T (1984) Anisomycin blocks the late phase of long-term potentiation in the dentate gyrus of freely moving rats. Brain Res 13:39-42.

Leach KL, Powers EA, Ruff VA, Jaken S, Kaufmann S (1989) Type 3 protein kinase $C$ localization to the nuclear envelope of phorbol ester-treated NIH 3T3 cells. J Cell Biol 109:685-695.

Lee W, Mitchell P, Tijan R (1987) Purified transcription factor AP-1 interacts with TPA-inducible enhancer elements. Cell 49:741-752.

Linden DJ, Routtenberg A (1989) The role of protein kinase C in long-term potentiation: a testable model. Brain Res Rev 14:279-296.

Lovinger D, Akers F, Nelson R, Barncs C, McNaughton B, Routtenberg A (1985) Selective increase in hippocampal protein $F 1$ phosphorylation directly related to three day growth of long-term enhancement. Brain Res 343:137-143.

Lovinger DM, Colley PA, Akers RF, Nelson RB, Routtenberg A (1986) Direct relation of long-term synaptic potentiation to phosphorylation membrane protein F1, a substrate for membrane protein kinase C. Brain Res 399:205-211.

Lovinger DM, Wong KL, Murakami K, Routtenberg A (1987) Protein kinase $C$ inhibitors eliminate hippocampal long-term potentiation. Brain Res 436:177-183.

Malenka RC, Madison DV, Nicoll RA (1986) Potentiation of synaptic transmission in the hippocampus by phorbol esters. Nature 321:175177.

Malenka RC, Kauer JA, Perkel DJ, Mauk MD, Kclly PT, Nicoll RA, Waxham MN (1989) An essential role for postsynaptic calmodulin and protein kinase activity in long-term potentiation. Nature 340 : 554-557.

Malinow R, Madison DV, Tsien RW (1988) Persistent protein kinase activity underlying long-term potentiation. Nature 335:820-824.
Malinow R, Schulman H, Tsien RW (1989) Inhibition of postsynaptic PKC or CaMKII blocks induction but not expression of LTP. Science 245:862-866.

Matthies H (1989) In search of cellular mechanisms of memory. Prog Neurobiol 32:277-349.

Mazzei GJ, Katch N, Kuo JF (1982) Polymyxin B is a more selective inhibitor for phospholipid-sensitive $\mathrm{Ca}^{2+}$-dependent protein kinase than for calmodulin-sensitive $\mathrm{Ca}^{2+}$-dependent protein kinase. Biochem Biophys Res Comm 109:1129-1133.

McCrimmon DR, Feldman JL, Speck DF (1986) Respiratory motoneuronal activity is altered by injections of picomoles of glutamate into cat brainstem. J Neurosci 6:2384-2392.

McNaughton BL (1982) Long-term synaptic enhancement and shortterm potentiation in rat fascia dentata act through different mechanisms. J Physiol 324:249-262.

Muller D, Turnbull J, Baudry M, Lynch G (1988) Phorbol esterinduced synaptic facilitation is different than long-term potentiation. Proc Natl Acad Sci USA 85:6997-7000.

Nishizuka Y (1986) The role of protein kinase C in cell surface transduction and tumour promotion. Nature 308:693-697.

Nishizuka Y (1988) The molecular heterogeneity of protein kinase C and its implication for cellular regulation. Nature 334:661-665.

Ono Y, Fujii T, Ogita K, Kikkawa U, Igarashi K, Nishizuka Y (1987) Identification of three additional members of rat protein kinase $C$ family: delta-, epsilon- and zeta-subspecies. FEBS Lett 266:125-128.

Otani S, Abraham WC (1989) Inhibition of synthesis in the dentate gyrus, but not the entorhinal cortex, blocks maintenance of long-term potentiation in rats. Neurosci Lett 106:175-180.

Popov NS, Reymann KG, Schulzeck K, Schulzeck S, and Matthies $H$ (1988) Alterations in calmodulin content in fractions of rat hippocampal slices during tetanic- and calcium-induced long-term potentiation. Brain Res Bull 21:201-206.

Reymann KG, Frey U, Jork R, Matthies H (1988a) Polymyxin B, an inhibitor of protein kinase $C$, prevents the maintenance of synaptic long-term potentiation in hippocampal CAl neurons. Brain Res 440: 305-314.

Reymann KG, Brodemann R, Kase H, Matthies H (1988b) Inhibitors of calmodulin and protein kinase $\mathrm{C}$ block different phases of hippocampal long-term potentiation. Brain Res 461:388-392.

Routtenberg A (1985) Protein kinase C activation leading to protein F1 phosphorylation may regulate synaptic plasticity by presynaptic terminal growth. Behav Neurol Biol 44:186-200.

Routtenberg, A, Lovinger D, Steward O (1985) Selective increase in the phosphorylation of a $47 \mathrm{kD}$ protein ( $\mathrm{F} 1$ ) directly related to longterm potentiation. Behav Neurol Biol 43:3-11.

Routtenberg A, Colley P, Linden D, Lovinger D, Murakami K, Sheu F-S (1986) Phorbol ester promotes growth of synaptic plasticity. Brain Res 378:374-378.

Sekiguchi K, Tsukuda M, Ogita K, Kikkawa U, Nishizuka Y (1987) Three distinct forms of rat brain protein kinase $C$ : differential response to unsaturated fatty acids. Biochem Biophys Res Comm 145:797802

Stanton PK, Sarvey JM (1984) Blockade of long-term potentiation in rat hippocampal CAl region by inhibitors of protein synthesis. $\mathbf{J}$ Neurosci 4:3080-3088.

Yamamoto KK, Gonazalez GA, Biggs WH III, Montminy MR (1988) Phosphorylation-induced binding and transcriptional efficacy of nuclear factor CREB. Nature 334:494-498. 